\title{
SUSTAINING PUBLIC-PRIVATE PARTNERSHIPS FOR PUBLIC SERVICE PROVISION THROUGH DEMOCRATICALLY ACCOUNTABLE PRACTICES
}

\begin{abstract}
Despite the multiple stakeholder-centered complexities involved, the Public-Private Partnership (PPP) modality is increasingly the vehicle of choice for the provision of public services in the developing world. This article asks how PPPs might overcome sustainability challenges in a meaningful way, while examining which stakeholdercentered interventions are effective in facilitating rather than undermining the continuity of the partnership operations. We draw on the notion of democratic accountability and an in-depth qualitative sector level case study in Uganda. The findings underscore the primacy practices that help to reduce stakeholder information asymmetry, increase partnerships' procedural legitimacy, and improve the understanding of substantive partnership outcomes.
\end{abstract}

Key words: Public services, Public-private partnerships, Democratic accountability, Stakeholders

\section{INTRODUCTION}

Cross-sector collaboration for the production and provision of public services is internationally well-established as a concept and a practice. Despite the existence of many variants of collaboration (Bryson, Crosby, \& Stone, 2006; Edelenbos \& Teisman, 2008; Selsky \& Parker, 2005), contractual Public-Private Partnerships (PPPs) have generated much wider practical traction and a considerable amount of discourse in recent times (Quelin, Kivleniece, \& Lazzarini, 2017; Soubliere \& Cloutier, 2015; Van Gestel, Willems, Verhoest, Voets, \& Van Garsse, 2014). Expansively defined as a long-term contractual arrangement involving the private sector in the 
delivery of public services (Brinkerhoff \& Brinkerhoff, 2011; Broadbent, Gill, \& Laughlin, 2008; Broadbent \& Laughlin, 2004), the model's international application spans a wide array of public policy sectors (Farrell \& Vanelslander, 2015; Hall, 2006; Ruckert \& Labonté, 2014).

Similarly, the model has drawn diverse streams of research and theoretical considerations as well as an extensive arena of rationalizations. Theoretically, PPP is considered prominently from collaborative governance (Adams, 2015; Ansell \& Gash, 2008; Nohrstedt, 2016), new public management (Hyndman \& Liguori, 2016), new public governance (Osborne, 2010) and post new public management (Christensen \& Laegreid, 2007) lenses. Furthermore, it is extensively rationalized, including as an antidote to fiscal and efficiency difficulties (Chen, 2010; Eriksson \& Hellström; Stafford \& Stapleton, 2017), an agile response to the increasing complexities of public problems (Brinkerhoff \& Brinkerhoff, 2011; Gray, 1989; Jacobs, 2010), a risk-sharing mechanism (Currie \& Teague, 2015; O'Flynn, 2009), and an instrument for ideological comprise (Bradford, 2003; Heuer, 2011). Most recently, the modality has also been posited as an instrument for fostering entrepreneurship at the local governance level (Xing, Liu, \& Cooper, 2018) and continues to be emphasized as a key governance instrument to address development challenges (L. Stadtler, 2015; Lea Stadtler, 2016; Vestergaard, Murphy, Morsing, \& Langevang, 2020). As a result, since the early 2000s, many countries in the developed and developing world have intensified efforts to establish the PPP as important framework of public service and infrastructure provision (World Bank, 2015, 2017).

However, multiple and inherent stakeholder complexities underscore the acute PPP continuity challenge in the operative phase (Diaz, Stallings, Birendra, \& Seekamp, 2015; Hayllar, 2010; Hertogh \& Westerveld, 2010; M. Hueskes, K. Verhoest, \& T. Block, 2017; Szmigiel-Rawska, 2016). Firstly, PPP arrangements involve the multiplicity of contractual 
arrangements with multiple actors that come together in a network of social connections, mutual commitments, and specific contract clauses to deliver the intended objective (Demirel, Leendertse, Volker, \& Hertogh, 2017; Hertogh \& Westerveld, 2010). Secondly, the long concession periods implies greater complexity and uncertainty as stakeholders change along with their interests and priorities ${ }^{1}$ (Kwak, Chih, \& Ibbs, 2009). Thirdly, different actors bring different strategies, procedures and loyalties to the project, leading to a high level of unpredictability (Bourne \& Walker, 2005). As a consequence, the model portends the inevitable interest alignment deficits in the course of its operations, thereby underscoring reported failures (Hayllar, 2010; Szmigiel-Rawska, 2016). In particular, stakeholder-related complexities appear to highlight the large volume of sunken investments, the persistent managerial instabilities, as well as perpetuate insufficient understanding of the intricacies in PPP environment (Cantarelli, van Wee, Molin, \& Flyvbjerg, 2012; Shaoul, Stafford, \& Stapleton, 2012; Stafford \& Stapleton, 2017).

Empirically, reports of PPP cancellations and distress are building. These involve, respectively, the private partner quitting a partnership by selling or transferring its economic interest back to the government before fulfilling the contract terms and the public sector partner or private sector operator either requesting a contract be terminated or seeking international arbitration to settle a dispute (M. Lee, Xuehui, Quising, \& Villaruel, 2018; World Bank, 2019). This disrupts public service provisions and discourages further private investment, while certain projects may require the commitment of public resources on payouts and as well as subsequent

\footnotetext{
${ }^{1}$ Notable stakeholder changes occur when a private partner changes or new entities join or leave consortium constituting the Special Purpose Vehicle. On the other hand, the public contracting partner may have its role or leadership revised by government policy changes.
} 
high-risk premiums (Fombad, 2016; Johnston \& Gudergan, 2007; C. H. Lee \& Yu, 2011; M. Lee et al., 2018).

This paper draws on the notion of democratic accountability and the empirical sectorlevel qualitative evidence from the electricity sector in Uganda to argue that specific accountability practices can facilitate long-term partnership continuity by acting as safeguards to stakeholder complexity risks. As we demonstrate in the subsequent parts, the findings suggest the efficacy of a set of vertical and horizontal stakeholder engagement practices, including (1) visibility and full disclosure reporting, (2) enabling of public access to partnership information, and (3) the participatory implementation of activities and projects that help to reduce partnership information asymmetry, increase partnerships' procedural legitimacy, and improve the understanding of substantive partnership outcomes.

This paper's contribution is threefold. First, context-specific sets of explanation for partnership sustenance are drawn. These help to address extant calls for both the need for partnership projects to be understood within their own context (Verweij, 2015) and a focus on lived practitioner experiences in the operative phase (Lenferink, Tillema, \& Arts, 2013a, 2013b). Second, as opposed to drawing from hindsight experiences from negative case studies, the use of a positive case study context foregrounds practically validated considerations in an underresearched context. Third, the study has underscored the potency of the notion of democratic accountability to understand and explain partnership sustenance. Further, to our knowledge, this is the first study to delineate and use sector-level perspectives as the unit of analysis in place of the specific project-level considerations prevalent in the extant PPP literature. 
The rest of this paper is structured as follows: In section two, we elaborate on the notion of democratic accountability and illustrate its efficacy in exploring stakeholder engagement in PPPs. The vertical and horizontal dimensional operationalizations of democratic accountability are emphasized in particular. Section three expounds on the methodology for the investigation. A brief description of Uganda's electricity sector as the context of investigation is provided, followed by the explanation of the qualitative and case study approach used here. The section also explains the empirical data collection and analysis protocols used. The key findings are presented and elaborated in sector four, followed by a discussion of the findings in the context of extant research and practice. Section five finishes with the conclusion, summarizing the key insights and potential routes for further work.

\section{THEORETICAL PERSPECTIVE}

\section{Democratic Accountability and PPPs}

Drawing on the broader realm of collaborative governance discourse (Agranoff \& McGuire, 2003; Ansell \& Gash, 2008; Donahue, Eggleston, Jing, \& Zeckhauser, 2013), we utilize the notion of 'democratic accountability' as the analytical lens. Democratic accountability is one of the foremost concerns of modern public policy and management (Behn, 2001; Lafont, 2010; Olsen, 2018) and the of 'democratic deficit' critique of PPPs (Gupta \& Verma, 2011; Hayllar, 2010; Willems, 2014; Willems \& Van Dooren, 2016). For instance, following an examination of PPP policies and projects in the People's Republic of China, Hayllar (2010) noted a direct and negative impact on PPPs' fulfillment of their potential, occasioned by a regular disregard of public views and the exclusion of the public from meaningful participation. 
Within the broader realm of collaborative governance, democratic accountability is conceptualized to involve transparency, i.e. an openness of decision-making processes in a way that is responsive to different authorizers, impacted stakeholders, and citizens (A. M. Bertelli \& Sinclair, 2018; Buse \& Walt, 2000; Holmen, 2011; Page, Stone, Bryson, \& Crosby, 2015). In line with the extant literature, we operationalize democratic accountability using vertical and horizontal attributes.

Vertical democratic accountability primarily includes responsiveness to authorizers and legal mandates. This conceptual attribute captures partnership's 'responsiveness to the actors and laws that provide it with funding and formal public authority and ensures that the collaboration's work is legal and is supported by the elected and appointed officials who grant it authority' (Page et al., 2015, p. 721). There are a plethora of indicators for vertical democratic accountability, such as a reduced resistance, objections, or sanctions from elected representatives or other public officials, public endorsements or other informal support from representatives or public agency officials, and Memorandum of Associations with public authorities (Hayllar, 2010; Page et al., 2015).

On the other hand, horizontal consideration in democratic accountability includes responsiveness to other collaborative partners and other impacted external stakeholders (A. M. Bertelli \& Sinclair, 2018; Hayllar, 2010; Page et al., 2015). This reflects a partnership's responsiveness to other (non-authorizing) actors who have a stake in the work and in a way that enables deliberation, continuous learning, and all-encompassing agreement among stakeholders on important issues (Hayllar, 2010; Holmen, 2011; O’donnell, 2003; Page et al., 2015; Relly, 2012; Schillemans, 2011). Like vertical democratic accountability, horizontal democratic accountability can be indicated by little or no resistance, objections, or legal challenges by 
stakeholders or the public, endorsements, Memoranda of Understandings, or informal forms of expression of support by key stakeholders as well as public opinion supportive of the partnership (Crosby, t Hart, \& Torfing, 2017; Hayllar, 2010; Page et al., 2015). In essence, horizontal democratic accountability processes denote how decisions and implementation can be aligned to respond to collaboration partners and other stakeholders.

While some theorists emphasize the direct role for citizens in democratic accountability practice (Boyte, 2011), in this paper we draw on extant practices in many democratic national contexts and consider representative perspectives. In other words, we do not draw perspectives and experiences of the private citizenry, rather our analytical dimensions consider indirect citizen representation through stakeholder and citizen groups via horizontal democratic accountability, and through elected authorizers and public duty bearers via vertical democratic accountability, on the supposition that representative actors can exercise meta-governance (Page et al., 2015; Sørensen \& Torfing, 2009).

\section{INSERT FIGURE 1 HERE}

To be sure, the notion of democratic accountability is particularly relevant for the core purpose of this inquiry, i.e. understanding how actors ensure the operational continuity of the PPPs in the context of inherently complex PPP operations, for two main reasons. First, the horizontal and vertical dimensions allow an exploration of the multi-level and multi-actor reality inherent in PPPs. Secondly, the concept enables the capture of different perspectives in a representative actor context, such as a PPP. Thirdly, the notion suits exploration in the context of the emergent considerations that require the transparent, open, and inclusive management of 
PPPs. This study is operationalized in an empirical context and using the approach elaborated below.

\section{EMPIRICAL CONTEXT AND METHODS}

\section{The Electricity Sector Reform in Uganda}

In Uganda, as in many parts of the developing world, the ideals of economic liberalization through the proliferation of the New Public Management agenda of the 1980s and 90s, in part, set the initial tone for the institutionally enabled participation of the private sector in the delivery in public services. This was subsequently enabled by the enactment of instructive institutional and legal frameworks. In 1993, Uganda passed the Public Enterprises Reform and Divestiture Act (PERD Act), which clustered the then public enterprises and prescribed the level of private sector participation in their operation. In the first class of enterprises, the state is required to retain $100 \%$ shareholding, in the second class of enterprises the state is supposed to retain a majority shareholding, and class three constitutes public enterprises which the state is required to fully divest from.

The Uganda Electricity Board (UEB), which was the government entity responsible for the production, transmission and distribution of electricity in the country, belonged to the second cluster of enterprises. To enable private sector participation, the Government of Uganda agreed to restructure the UEB as part of the sector reform process. The vertically integrated UEB was then unbundled to create three separate business units of generation, transmission, and distribution. Successor public companies, namely Uganda Electricity Generation Company Limited (UEGCL), Uganda Electricity Transmission Company Limited (UETCL) and Uganda 
Electricity Distribution Company Limited (UEDCL), were incorporated to own the assets and operate the generation, transmission and distribution business units, respectively.

In addition, the electricity sector reforms also included the enactment of the Electricity Act of 1999, which provided for the creation of the independent regulatory authority to oversee the operations of the sector. The Electricity Regulatory Authority (ERA) became operational in 2000, with the mandate to issue electricity generation, transmission, and distribution licenses, set license conditions, and ensure compliance to license conditions by licensees. In addition, ERA is also mandated to establish a tariff structure and approve rates of charges, among other functions. Procedurally, ERA is duty-bound to conduct its functions in an open, objective, fair, reasonable, non-discriminatory, and transparent manner and also promote fair competition. ERA ensures that utilities earn the reasonable rate of return on their investments necessary to provide a quality service at affordable prices to the electricity consumer.

\section{Electricity Generation, Transmission and Distribution Partnerships}

From 2003 to 2018, the number of active contractual-type PPP projects increased from 3 to 25, with a total investment of $\$ 1.568$ billion (World Bank, 2019). Since the liberalization of the electricity sector, the partnerships have accelerated the growth in generation capacity from 359.5 MW to the current 601.1 MW. Total installed generation capacity has grown from $60 \mathrm{MW}$ in 1954 to over $682 \mathrm{MW}$ with a diversified generation mix energy sources, including hydro at 459 MW, thermal at $100 \mathrm{MW}$, and cogeneration at $41 \mathrm{MW}$. The number of private electricity distribution companies increased from one distributor (UEB) to eight operating in various regions of the country.

\section{FIGURES 1 AND 2 HERE}




\section{Data Collection}

Semi-structured interviews and a document review are the two primary data collection methods applied in the study. Twenty-eight (28) interviewees with direct current and/or retrospective experience with electricity sector operations were drawn from the regulatory agency, government departments and agencies, public and private sector partner organizations, and local and international consulting firms (Appendix 1) through a snowballing technique (Miles \& Huberman, 1994). Snowballing was useful for two reasons. First, there is only a very limited pool of people who have direct experience with the operations and PPP arrangements of the sector. Second, PPPs in Uganda are generally seen as commercial transactions whose internal workings remain largely protected under commercial confidentiality (see similar justifications in Beyene, 2014; Opawole \& Jagboro, 2017). The semi-structured interview data were complemented with a review of reports by the independent sector regulator, concession agreements, partner's organization reports, press releases, and media reporting (appendix 2). The review helped in corroborating some important retrospective interviewee experiences and perspectives (Bowen, 2009), some of which dated back 15 years from the time of the interview.

\section{Data Analysis}

Qualitative Data Analysis Software (QDAS) NVIVO 12 was utilized to facilitate the analysis of the text data. The data were analyzed through a code system by means of thematic analysis undertaken in three iterative cycles (Bernard \& Ryan, 2010; Saldaña, 2015), guided deductively (Fereday \& Muir-Cochrane, 2006) by the operationalized attributes of democratic accountability elaborated earlier.

First, a process coding approach was used in which observable activities and/or conceptual activities were assigned to the appropriate democratic accountability attribute, 
generating an elaborate list of coded observations. In the second cycle of coding, the observations from cycle one were re-coded based on their meaning and conceptual relatedness to generate a list of issue-based categories/processes. In the final cycle, the list of issue-based processes was further categorized and abstracted into three broader themes based on underlying meaning (codebook in appendix 3), as presented and illustrated below.

\section{FINDINGS}

The analysis of the data reveals important democratic accountability processes utilized by the partnership actors in the electricity sector in Uganda (see summary in Table 1). The three categories, namely visibility and full disclosure in reporting, enabling public access to partnership information and stakeholder consultation, and participatory implementation, are presented and elaborated below.

\section{TABLE 1 HERE}

\section{Visibility and Full Disclosure in Reporting}

The generation and sharing of reports among partners appear to comprise an important tool used by actors in the partnership to shape their decision-making, perceptions and expectations. In particular, the evidence indicates that partners ensure that partnership operations are visible between themselves and with other stakeholders through periodic reviews and cascaded reporting.

Firstly, periodically different types of reviews of the partnership are conducted. These reviews include seven-year reviews, quarterly reporting, and monthly reports (Interview 4, 2018; 
Interview 5, 2018; Interview 18, 2018). In regard to the seven-year reviews, after every seven years of the implementation, a review of the partnership is conducted. The reviews focus on licensing, budgets, and performance targets. Thereby, not only are the provisions of the licensing, the budgetary provisions and the performance targets subjected to a thorough process that takes into consideration the wider circumstances and expectations of actors, but it is also ensured that the commitments are in the open and known to the actors. As this quote illuminates:

[..] but lucky for us, between ourselves and ERA, we have periodic reviews, every seven years we review the license, the budgets, the performance targets, so we are under the discussion 2019-2025, what are the operation budgets, what are thresholds of past performance, what's the requirement on investment side, so once we lock in those figures the problem comes in managing any excesses because you can say we are going to grow by $5 \%$ as a sector then we grow like $6 \%$ or $7 \%$, (so) who is going to finance that additional growth? That is the grey area for us...so that is (a) dominant side of our discussions from time to time (Interview 4, 2018).

As the quote highlights, locking in the expectations for the period helps to ensure that the expectations of actors are clear and tractable. Although locking in the figures for the period is important for clarity, the above quote also suggests that unexpected deviations often emerge and need to be managed. But, as might be expected, periodic review schedules have not been seamless as they tend to be affected by external actions that distort the review timelines, blurring the intention of periodic reviews. As the senior manager at the regulatory authority reflects in the quote, the actions of external actors occasionally distort the timelines and impact the review objectives: 
[...] one critical term that was agreed [was] (contractual terms and conditions at contracting) that we (partners) all don't know what the loss (energy losses) is, let's operate for 5 years and in the 5th year lets study the losses, or we would have done studies on the loses such that we adjust for that. What materialized is that after 4 and half years, politics kicked in. Instead of following the agreement to look at how can we tighten through the agreement using technocrats who know what they are doing, we (government) started saying kick them (private sector partners) out, they are taking a lot of money and so on and so forth [...]. So when the numbers finally came to the table that this is how much to pay [to terminate], the timeline for negotiating and tightening the agreement had passed (Interview 21, 2018).

As reflected in above quote, these reviews are altered by different interests that distract from both the objectives and different sets of expectations that need to be addressed.

The other periodic reviews are the monthly and quarterly reviews of the partnership. These in particular provide an opportunity for the regulatory authority and the operator to raise and address queries on a continual basis. In the monthly report, management accounts of the operator are shared with the regulator, while on the quarterly basis both the regulator and the UEDCL review the capital investments made by the private operator (Interview 4, 2018; Interview 23, 2018; Interview 27, 2018). As an interviewee from a private sector partner depicts the process in the quote below:

We report to them (ERA) on a monthly basis. On a quarterly basis, they have to come and review our capital investments. Then, on a monthly basis we give them our management accounts. They look through and (if they) have queries and we have that kind of 
conversation. Then, as you know, we are private entity which is listed on the stock exchange, so we have auditors also come in review and issue out whatever to investors and the public and the regulator and even us (Interview 4, 2018).

The second part of this intervention involves cascaded reporting. Based on the evidence, this involves the regular sharing of reports among actors in the partnership and, as necessary, with the external stakeholders, which facilitates transparency and disclosure (Interview 23, 2018). Among the direct partnership actors, a practice of cascaded interaction ensures that actors in the partnership are informed of the decisions and any rationalization informing such decisions. In other words, reports are not only shared for information purposes but also to seek the input of others. In the illumination below by an interviewee from the regulatory authority, a depiction is made of actors aligning themselves through cascaded reporting processes from the operator through UEDCL to the regulatory authority:

[...] but even more commonly now what has been happening is that when, for example, there is a submission going to be made by the concessionaire (UEDCL), they will first pass it by the asset owner (UEDCL), then by the time it is literally delivered here at least they (UEDCL) would have an eye and they have no objection per se; so sometimes, its only us, sometimes it looks disappointing but there are cases where the asset owner will say yes, but then the regulator will say no because of the assessment from the regulatory perspective not from a corporate perspective (Interview 23, 2018).

Such cascaded interaction facilitates the visibility of operations among the interacting partners, which enables the reconciliation of the expectations arising from reduced information asymmetry, especially among partners and other external stakeholders (Interview 4, 2018). 


\section{Public Access to Partnership Information and Stakeholder Consultations}

Enabling public access to partnership-related information is also an emphasized mechanism. First, as a practice, information on some of the important decisions made regarding the implementation of the partnership is made available to the public. Specifically, the Electricity Regulatory Authority provides important information on specific reports and general information on the sector, including information on ongoing partnerships. As one of the interviewees explained, the purpose is to enable open access to the decision-making processes by the public and allow the stakeholders to validate the decisions against the set procedures:

We have departments, we have technical regulation, the engineers, we have the lawyers, we have people who do investment verification and all those things but all that needs money and we put in the tariff. So, we have all these documents on our website, tariff setting guidelines, tariff code, section 75 of the Act (Interview 27, 2018).

In making important information available for public access, the actors assume that stakeholders will be aware of the important issues that lead to the decisions on the actor's actions.

Secondly, information is provided to the stakeholders through direct engagements. These take different forms, including consultations with the various stakeholders and/or their representatives and through responding to the queries of oversight public authorities such as the parliamentary committees (Interview 3, 2018; Interview 9, 2018; Interview 28, 2018). In engaging the stakeholders, the interview evidence suggests that the focus is on seeking an understanding from both the actors and stakeholders involved and seeking an amicable settlement for differences. 
[..] sometimes you end up engage political representatives who is putting pressure like the Resident District Commissioners (RDCs), so you would have to engage the RDCs then the police structure because sometimes they can get violent (service users) when you are going to disconnect (electricity service)....Some for instance engagement with millers, managing stakeholder expectations because many times we have had joint sessions to explain to customers, especially on the pricing (Interview 28, 2018).

Moreover, the evidence also suggests that engagement with stakeholders has also focused on educating stakeholders on the different mandates of the different players in the sector (Interview 3, 2018; Interview 27, 2018; Interview 28, 2018). The interview evidence shows that actors in the partnership, particularly the private operators whose public opinion and brand image are at risk from misplaced critique, make attempts to engage the different stakeholders to provide information on the distinctive roles of the actors. As the quote from the interviewee from the private operator clearly puts it:

The other one you look at, who is the other interested party, is the public legislative team in parliament. We have had a frosty relationship with parliament - it's understandable! it's understandable! Why? The parliament represents $100 \%$ of the population and $77 \%$ of the population has no access to the grid (electricity), of course they will be fighting for them. Unfortunately, they will be looking at you because you are the face of the sector to reach all those guys as fast as you can, and they represent the interest of the masses. Now that is where we have had a frosty relationship but our role is to continue engaging, educating them to ensure that they understand what we do and that rural electrification drives the other agenda of the masses (Interview 3, 2018). 
Essentially, it appears that increasing stakeholder knowledge about the sector and the roles of different sector players would help address any misconceived attributions of responsibility in a way that aligns stakeholder perceptions with the realities of the partnership.

\section{Participatory Implementation}

Moreover, the evidence points to actors' joint participation in activities and on special projects. First, the interview evidence highlights that in situations where there are identical processes and or actions of mutual interest to actors, the actors often agree to jointly execute or align the execution of such activities. The evidence reveals particular joint activities undertaken in this partnership, including asset and investment verifications and joint intersectorial reviews (Interview 3, 2018; Interview 4, 2018; Interview 18, 2018; Interview 23, 2018). This is in a bid to save resources, harmonize information among actors, and pursue common public service objectives. As the following quote illuminates, the common objective is to achieve efficiency as all actors understand the common obligation and the importance of the synchronization of activities:

[...] for example, investment verification, we have a responsibility and the public sector partner has a responsibility. For example, when we are conducting investment verification, this activity is not undertaken only by the regulator, we go hand-in-hand with the asset owner and regulator. Everywhere we shall go and when, for example, there is a proposal by the regulator or even sometimes by the utility, the asset owner themselves, no this should not happen or no we are rejecting this because of xyz and we have no grounds for example to say no you include it, no we shall not do that. So. because the operations have a similarity in a way, although what we are looking for is in 
some cases different from what they are looking for, we generally move together (Interview 23, 2018).

The evidence suggests that the joint execution of the review enables a functional synchronization of electricity sector information in regards to the priorities and actions of other actors (Interview 4, 2018; Interview 23, 2018). In conducting reviews, common issues of concern across the sector are considered with the input of various actors in the value chain that affect and/or are affected by a particular action. As the quote below illustrates, cross-cutting issues of concern, such as the need to lower the tariffs, are considered with input from various contributing actors:

[..] we've had that discussion on the tariff and said how do we manage this tariff downwards, there are certain interventions, building demand, its actually an inter-sector institution review committee that's looking at what's the demand trajectory like, how can we stimulate more demand because the price is just...equals, in mathematics, the cost, the revenue divide by the demand, so if you grow the demand less, you reduce the cost of the customer or, for example, if you look at now a upstream component because, believe me, the upstream component is about $70 \%$ of the tariff (Interview 4, 2018).

Besides sharing information and jointly considering options to address the common issues, the joint sector review is an engagement platform that aids in reducing ambiguities and any contradictions in the course of implementation. More specifically, as the interviewee observes below, it enables engagement with a wide range of actors on a broad variety of issues:

It's dual, it's by proxy through ERA especially things to do with tariffs, investments but the ministry of energy is the chair entity or person in the interinstitutional sector review 
committee. Looking at the entire sector broadly, demand, supply all those issues, so we have that engagement with them, first and foremost (Interview 4, 2018).

Secondly, there is the joint implementation of special projects by actors. Like the preceding finding on the joint implementation of activities, special projects include sector-wide initiatives developed to support the sector. The interview evidence indicates that most of these projects have been supported either by government or development partners and have focused on enabling affordability and access (Interview 4, 2018). Through actors jointly participating in delivering these projects, the evidence suggests that actors have the opportunity to identify challenges first-hand and design and synchronize responses based on mutual learning from each other.

In particular, the projects appear to provide an opportunity to connect practical challenges in the design of policy options and methods of policy implementation in a way the addresses not only the important sector issues generally, but also those integral to the distribution partnership (Interview 3, 2018; Interview 4, 2018; Interview 23, 2018). In the excerpt below, the interviewee from the private operator who is familiar with the ongoing projects clearly illustrates these rationales and the interactions:

[..] we've had the World Bank OBA project, we've had the Kawanda transmission line corridor, that one which dealt directly with them and of course KFW, we have had the connection policies coming on board to kick-start that connection, to revolving the fund, subsidization of the customer, so they involve us (sector players) in the policy discussions, then of course for us we implement, but we are involved in that discussion at that level to (help) understand operational issues that may come up. We give them advice, 
then they go back and say okay based on our assessment, this is the best direction we should take, we've raised these particular funds can you please implement (Interview 4, 2018).

In essence, through participatory special project implementation, it is suggested that information is shared and ideas are exchanged to help actors be informed at both the partnership and sectorwide levels.

\section{DISCUSSION OF FINDINGS AND REVISITING DEMOCRATIC ACCOUNTABILITY}

As presented and illustrated, the evidence has pointed to the primacy of six processes presented in the three themes of (1) visibility and cascaded reporting, (2) public access to partnership information and stakeholder consultation, and (3) participatory implementation of activities and of special projects. As highlighted in the extant literature, part of the social risks to partnerships emanates from limited stakeholder knowledge and understanding about the partnership, which results in the mismatch of expectations between the partnership's stakeholders. One of the essential ideas across all the identified accountability mechanisms is to create an opportunity for the diverse stakeholders to construct informed opinions, judgments and responses to the partnerships that are based on an accurate understanding of the important realities of the partnership. The evidence suggests that all the strategies should be premised on the understanding that stakeholder's limited information on and involvement in the partnership generate a limited understanding of the partnership's scope of responsibility, challenge the partnership's legitimacy, and undermine the efficacy of partnership outcomes.

Indeed the applied strategies in this case targeted different stakeholder groupings, such as individual end-users, policy-makers and user representatives and appeared to be essential bridges 
to such deficits. It specifically appears that the end-user strategies are geared towards providing information ensuring that they understand the different service provision protocols, such as tariff determination and administration. The strategies also focus on ensuring that end-users understand their obligations as these relate to the services provided. In addition, the evidence suggests that the informational provision strategies centrally adopted for other value chain actors and policy actors are intended to clarify the different actor obligations and commitments made in relation to the partnership between the public sector and the private partner.

In the case of Uganda, it is also important to understand the peculiarity and critically of stakeholder involvement from the fact that the PPP model is new to most stakeholders. As such, at all different levels, as expected, there is a lingering lack of understanding and acceptance of the private provision of public services. Indeed, the difficulties in partnership related to capacity (and particularly knowledge gaps) are an issue articulated by many scholars of interorganizational, cross-sector partnerships and PPP research (Anthony M Bertelli, 2016; Boyer, 2016; Grossman, 2012; Page et al., 2015; Smeets, 2017). Boyer (2016), for instance, explains that public infrastructure projects of all forms face public resistance due to the wide spectrum of constituents affected by their development. And, in the particular case of PPPs, additional challenges are bound in building and sustaining public support because of the role that foreign companies often play in the delivery of services and the introduction of user fees that may not have been in place before. These realities in the case of PPPs are often exacerbated as many of the details of a PPP are not disclosed until after a private partner has been selected and the project is operational. Similarly, Grossman (2012) articulates the challenges related to information asymmetries and diverging preferences that blur responsibilities and tend to move 
the delegation instead to abdication and a shirking of responsibilities by both the private and public actors.

In light of that, the plugging of information gaps is critical as the different actors' responsibilities are thereby clarified to many stakeholders who may not be privy to the workings and commitments of the partnership. In so doing, actors can still be held responsible on the one hand, and on the other hand, no actor takes responsibility for actions they should not be held responsible for. In addition, the information provided appears to help manage the expectations of different stakeholders, or at least synchronize the diverging expectations - some of which are illinformed due to no or poor information. Indeed, the centrality of the engagement of stakeholders, broadly construed, by way of sharing information is not a peculiar finding of this study. Extant research in PPP management and other interorganizational research has pointed to the primacy of building stakeholder capacity (Hudson, Hardy, Henwood, \& Wistow, 1999; Löfström, 2010; Wilkins, Phillimore, \& Gilchrist, 2016) and information sharing for successful partnership (Cuganesan, Hart, \& Steele, 2017; Wilkins et al., 2016; Wilkins, Phillimore, \& Gilchrist, 2017; Yoo, Hawryszkiewycz, \& Kang, 2013). The sharing of information has particularly been associated with many different facets of collaboration, including for the achievement of outcomes (Wilkins et al., 2017), creating clarity in expectations to enable each partner to know what is expected of them (Ryan \& Walsh, 2004), and decision-making (Cuganesan et al., 2017). In other words, information issues, including communication and engagement with stakeholders, are raised as a way to enhance collaboration in a similar way to what this investigation has suggested and underscored.

That notwithstanding, the approach adopted in the context of Uganda provides further insight in the terms of the apportionment of responsibility for the sharing of partnership 
information and other forms of involvement. First, it appears that from the public sector actors, the regulatory authority is making attempts to provide information and clarity with very limited input from the substantive public partner agencies (UEGCL, UETCL, UEDCL). The approach appears to aim at creating an image of transparency of the regulator in general rather than a focus on the partnership. In fact, the partnership is mentioned consistently and addressed more as independent private actors with only delegated and regulated authority rather than a partnership with multiple responsibility lines. The regulatory authority also provides information primarily in line with the rules developed by itself, rather than based on rules relevant for the functioning of the partnership, particularly as enshrined the contract. And most of this information is provided in the form of documents uploaded to the website. This appears to be the first alternative.

The second information sharing process is conducted by the private sector partners. This appears to focus on commercial stakeholders and uses commercial approaches to reach the stakeholders. While it projects the commercial aspects of the company, the approach does not answer the concerns that drive difficulties, which in fact, as the preceding sections illuminate, are founded on perceptions of the contractual terms. For instance, the private partner does not address issues of scope or of distribution of responsibility and tariffs. which appear to premise most of the challenges. The inability of either party to delve into the actual contractual commitments means that the challenges, as they relate to external stakeholders, will most likely remain as they cannot be side-stepped by commercial approaches or selective disclosure' as a result, this reinforces the perceptions already formed by some stakeholders. In all, the actors focus on providing information to the stakeholders but it appears that the provision of information does not address the central premises of the challenges, which are centered on contractual provisions - although no actor appears to provide a specific address. 


\section{Revisiting Democratic Accountability}

The dimensions of democratic accountability fit well with the stakeholder dilemmas in PPPs. From the vertical accountability consideration, the findings depict actors adopting a shared interpretation of the problems and crafting solutions, focusing on macro-level rather than microlevel processes, as well execution action as informed by what is considered appropriate action by the authorizing stakeholders. An example includes making appropriate responses to the Auditor General reports to the Parliament of Uganda on the findings and queries to the committee of Parliament responsible for Commissions, Statutory Authorities and State Enterprises (COSASE) and subsequently appearing before the Committee of Parliament to respond to the queries. In addition, there is compliance with the legally mandated declarations, like the publication of audited accounts in which information is shared with the different stakeholders to ensure they understand and appreciate the courses of action of the partnership and are able to give to in the decision-making process as and when necessary. The partnership actors acting together or separately have to comply with these kinds of mandated information sharing and engagement requirements.

Horizontally, the engagement with non-authorizing stakeholders is equally reflected in how partnership actors share information and engagement among partners and with end-users. This includes the execution of joint stakeholder consultations by the regulatory authority, public sector participating agencies, private partners and the different categories of end-users. This suggests that the different stakeholders determined that it was the appropriate course of action to take. Similarly, the actors' joint execution of some projects suggests that the actors found it imperative to have common areas to exchange ideas and address common challenges across the sector stakeholders. 


\section{CONCLUSION}

For the policy actors and practitioners involved in enhancing the long-term operations of PPPs the implications can be summed up as follows. First, the diverse parties of interest, including individual and composite actors, need to be comprehensibly and continually mapped, both horizontally and vertically, as an acknowledgement of the potency as an avenue for counterproductive contradictions and as a recognition of the emergent and evolving nature of stakeholders, respectively. Otherwise, stakeholder interests will remain latent, only to emerge as stakeholder opposition that undermines the partnership's purpose. Second, PPP managers must undertake context-relevant initiatives so that both authoring and non-authorizing stakeholders see the partnership as accountable for both processes and results in a way that is relevant to the public interest. Third, where sector-level linkages and sector service value chain relations are inevitable, as in this case, the value of joint actor forums through interagency committees or working groups should be explored, especially when constituted by strategic-level actors with greater experience, expertise and decisional influence. Finally, where an independent legal authority exists to regulate the operations of the sector, different partners should consider it as a platform addressing overarching sector-level concerns with other stakeholders to guard against inaccurate attributions and potential partner conflict arising from partners' self-preserving and commercial interest responses, which could disenfranchise other stakeholders or the broader citizenry.

In closing, it is imperative to recognize the caveats and limitations of the study. First, the findings and implications are based on experiences from concession-type partnerships from a single sub-sector (electricity), one policy domain (energy) and draws some perspectives from elected representative actors whose political behavior and relationship with voters (citizenry) 
cannot be ascertained within scope of this work. Thus caution must be used when interpreting the results. Second, in this study context an independent regulatory entity plays an active role, utilizing additional control instruments such as licenses to exert control on and influence the actions of partnerships across the sector. This is an active role in constituting and facilitating vertical and horizontal engagement in the sector. It is, therefore, not possible to determine whether certain stakeholder engagement processes would be possible without the influence of the authority, especially in partnerships that are purely monitored by contracting public agencies through predetermined contract provisions. Third, partnership sustainability in this study has a general conception and focuses primarily on partnership continuity, that is, the partnership is active (Szmigiel-Rawska, 2016); however, the other specific dimensions of sustainability (Gupta \& Verma, 2011; Marlies Hueskes, Koen Verhoest, \& Thomas Block, 2017) are worth considering with a sufficient level of detail. Finally, this study does not provide summative findings as it is conducted at the early to mid-stages of the partnership operations in the sector. It is, therefore, not possible to ascertain if the measures undertaken will remain relevant in light of any changed circumstances in the future. These caveats need to be incorporated in future research.

Several interesting future research avenues also arise from the study, three of which are outlined here. First, given the very limited scope of prior work on the sustainability of PPPs in developing country contexts and the absence of work addressing democratic accountability in energy sector PPPs, further work in the form of intensive case studies would be useful, especially given the theory-building benefits of this approach (Eisenhardt, 1989). Second, future work could expand the policy domains and explore partnership sustainability across sectors - such as health, education, water and sanitation partnerships - to increase the generalizability of any 
findings. Finally, the multidimensionality of the concept of sustainability means that our consideration here of a partnership's continued operation is only a limited contribution; more can be addressed in future work by addressing specific facets of partnership sustainability. 


\section{REFERENCES}

Adams, D. (2015). collaborative governance and collaborative governance regimes. Collaborative Governance Regimes, 14.

Agranoff, R., \& McGuire, M. (2003). Collaborative public management: New strategies for local governments: Georgetown University Press.

Ansell, C., \& Gash, A. (2008). Collaborative governance in theory and practice. Journal of Public Administration Research and Theory, 18(4), 543-571.

Behn, R. D. (2001). Rethinking democratic accountability: Brookings Institution Press.

Bernard, H., \& Ryan, G. W. (2010). Content analysis. Analyzing qualitative data: Systematic approaches, 287-310.

Bertelli, A. M. (2016). Who are the policy workers, and what are they doing? Citizen's heuristics and democratic accountability in complex governance. Public Performance \& Management Review, 40(2), 208-234.

Bertelli, A. M., \& Sinclair, J. A. (2018). Democratic Accountability and the Politics of Mass Administrative Reorganization. British Journal of Political Science, 48(3), 691-711. doi:10.1017/s0007123416000077

Beyene, T. T. (2014). Factors for implementing public-private partnership (PPP) in the development process: Stakeholders' perspective from Ethiopia. International Journal of Science and Research, 3(3), 792-797.

Bourne, L., \& Walker, D. H. (2005). Visualising and mapping stakeholder influence. Management Decision, 43(5), 649-660.

Bowen, G. A. (2009). Document analysis as a qualitative research method. Qualitative research journal, 9(2), 27-40.

Boyer, E. J. (2016). Identifying a Knowledge Management Approach for Public-Private Partnerships. Public Performance \& Management Review, 40(1), 158-180. doi:10.1080/15309576.2016.1204928

Boyte, H. C. (2011). Constructive politics as public work: Organizing the literature. Political Theory, 39(5), 630-660.

Bradford, N. (2003). Public-private partnership? Shifting paradigms of economic governance in Ontario. Canadian Journal of Political Science-Revue Canadienne De Science Politique, 36(5), 1005-1033.

Brinkerhoff, D. W., \& Brinkerhoff, J. M. (2011). Public-private partnerships: Perspectives on purposes, publicness, and good governance. Public Administration and Development, 31(1), 2-14. doi:10.1002/pad.584

Broadbent, J., Gill, J., \& Laughlin, R. (2008). Identifying and controlling risk: The problem of uncertainty in the private finance initiative in the UK's National Health Service. Critical Perspectives on Accounting, 19(1), 40-78.

Broadbent, J., \& Laughlin, R. (2004). PPPs: Nature, development and unanswered questions. Australian Accounting Review, 14(33), 4-10.

Bryson, J. M., Crosby, B. C., \& Stone, M. M. (2006). The design and implementation of Cross-Sector collaborations: Propositions from the literature. Public Administration Review, 66(s1), 44-55.

Buse, K., \& Walt, G. (2000). Global public-private partnerships: part II-what are the health issues for global governance? Bulletin of the World Health Organization, 78(5), 699-709.

Cantarelli, C. C., van Wee, B., Molin, E. J., \& Flyvbjerg, B. (2012). Different cost performance: different determinants?: The case of cost overruns in Dutch transport infrastructure projects. Transport Policy, 22, 88-95. 
Chen, B. (2010). Antecedents or Processes? Determinants of Perceived Effectiveness of Interorganizational Collaborations for Public Service Delivery. International Public Management Journal, 13(4), 381-407. doi:10.1080/10967494.2010.524836

Christensen, T., \& Laegreid, P. (2007). Transcending New Public Management: The Transformation of Public Sector Reforms. Aldershot: Ashgate.

Crosby, B. C., t Hart, P., \& Torfing, J. (2017). Public value creation through collaborative innovation. Public Management Review, 19(5), 655-669. doi:10.1080/14719037.2016.1192165

Cuganesan, S., Hart, A., \& Steele, C. (2017). Managing information sharing and stewardship for publicsector collaboration: a management control approach. Public Management Review, 19(6), 862879. doi:10.1080/14719037.2016.1238102

Currie, D., \& Teague, P. (2015). Conflict Management in Public-Private Partnerships: The Case of the London Underground. Negotiation Journal, 31(3), 237-266.

Demirel, H. Ç., Leendertse, W., Volker, L., \& Hertogh, M. (2017). Flexibility in PPP contracts-Dealing with potential change in the pre-contract phase of a construction project. Construction Management and economics, 35(4), 196-206.

Diaz, J. M., Stallings, K. D., Birendra, K. C., \& Seekamp, E. (2015). Evaluating multi-institutional partnership sustainability: a case study of collaborative workforce development in renewable energy assessment. Educational Research and Evaluation, 21(5-6), 466-484. doi:10.1080/13803611.2015.1121833

Donahue, J., Eggleston, K., Jing, Y., \& Zeckhauser, R. (2013). Collaborative Governance in China's Health Sector: A Comparison with Education, Housing, and Long-Term Care. In: Stanford Asia Health Policy Program working paper.

Edelenbos, J., \& Teisman, G. R. (2008). Public-private partnership: on the edge of project and process management. Insights from Dutch practice: the Sijtwende spatial development project. Environment and Planning C: Government and Policy, 26(3), 614-626.

Eisenhardt, K. M. (1989). Building theories from case study research. Academy of management review, 14(4), 532-550.

Eriksson, E., \& Hellström, A. Multi-actor Resource Integration: A Service Approach in Public Management. British Journal of Management.

Farrell, S., \& Vanelslander, T. (2015). Comparison of Public-Private Partnerships in Airports and Seaports in Low- and Middle-Income Countries. Transport Reviews, 35(3), 329-351. doi:10.1080/01441647.2015.1015066

Fereday, J., \& Muir-Cochrane, E. (2006). Demonstrating rigor using thematic analysis: A hybrid approach of inductive and deductive coding and theme development. International journal of qualitative methods, 5(1), 80-92.

Fombad, M. C. (2016). Governance in Public-Private Partnerships in South Africa: Some Lessons from the Gautrain. Journal of Southern African Studies, 41(6), 1199-1217. doi:10.1080/03057070.2015.1117240

Gray, B. (1989). Collaborating: Finding common ground for multiparty problems.

Grossman, S. A. (2012). The management and measurement of public-private partnerships: Toward an integral and balanced approach. Public Performance \& Management Review, 35(4), 595-616.

Gupta, P. K., \& Verma, H. (2011). Public-Private Partnerships for Infrastructure Projects: Sustainability Issues and Critical Success Factors.

Hall, A. (2006). Public-private sector partnerships in an agricultural system of innovation: Concepts and challenges. International Journal of Technology Management \& Sustainable Development, 5(1), 3-20. doi:10.1386/ijtm.5.1.3/1 
Hayllar, M. R. (2010). Public-Private Partnerships in Hong Kong: Good Governance - The Essential Missing Ingredient?1. Australian Journal of Public Administration, 69, S99-S119. doi:10.1111/j.1467-8500.2010.00675.x

Hertogh, M., \& Westerveld, E. (2010). Playing with Complexity. Management and organisation of large infrastructure projects.

Heuer, M. (2011). Ecosystem Cross-Sector Collaboration: Conceptualizing an Adaptive Approach to Sustainability Governance. Business Strategy and the Environment, 20(4), 211-221. doi:10.1002/bse.673

Holmen, A. K. T. (2011). Governance Networks in City-Regions: In the Spirit of Democratic Accountability? Public Policy and Administration, 26(4), 399-418.

Hudson, B., Hardy, B., Henwood, M., \& Wistow, G. (1999). In pursuit of inter-agency collaboration in the public sector: What is the contribution of theory and research? Public Management an International Journal of Research and Theory, 1(2), 235-260.

Hueskes, M., Verhoest, K., \& Block, T. (2017). Governing public-private partnerships for sustainability An analysis of procurement and governance practices of PPP infrastructure projects. International Journal of Project Management, 35(6), 1184-1195. doi:10.1016/j.ijproman.2017.02.020

Hueskes, M., Verhoest, K., \& Block, T. (2017). Governing public-private partnerships for sustainability: An analysis of procurement and governance practices of PPP infrastructure projects. International Journal of Project Management, 35(6), 1184-1195.

Hyndman, N., \& Liguori, M. (2016). Public Sector Reforms: Changing Contours on an NPM Landscape. Financial Accountability \& Management, 32(1), 5-32.

Interview 3 (2018, June). [Semi structured interview with Private partner reprsentative in the Electricity Distribution Concession in Uganda].

Interview 4 (2018, April). [Semi structured Interview with representative of Private Partner in the Electricity Distribution concession in Uganda]. Oral face to face.

Interview 5 (2018, March). [Semi structured interview with representative of the Private Partner in the Electricity Distribution concession in Uganda]. Oral face to face.

Interview 9 (2018, June). [Semi structured interview with an official in Governnment department knowledgable about the Electricity distribution concession]. Oral.

Interview 18 (2018, June). [Semi structured interview with a representative of the public sector partner in Electricity distribution concession in Uganda]. Oral.

Interview 21 (2018, June). [Semi-structured Interview with an official from the Electricity Regulatory Authority about the UMEME - UEDCL Electricity Distribution Concession]. Oral.

Interview 23 (2018, April). [Semi-structured Interview with an official from the Electricity Regulatory Authority about the UMEME - UEDCL Electricity Distribution Concession]. Oral.

Interview 27 (2018, May). [Semi-structured Interview with an official from the Electricity Regulatory Authority about the UMEME - UEDCL Electricity Distribution Concession]. Oral.

Interview 28 (2018, May). [Semi-structured Interview with an official from the Electricity Regulatory Authority about the UMEME - UEDCL Electricity Distribution Concession]. Oral.

Jacobs, K. (2010). THE POLITICS OF PARTNERSHIPS: A STUDY OF POLICE AND HOUSING COLLABORATION TO TACKLE ANTI-SOCIAL BEHAVIOUR ON AUSTRALIAN PUBLIC HOUSING ESTATES. Public Administration, 88(4), 928-942. doi:10.1111/j.1467-9299.2010.01851.x

Johnston, J., \& Gudergan, P. S. (2007). Governance of public-private partnerships: lessons learnt from an Australian case? International Review of Administrative Sciences, 73(4), 569-582.

Kwak, Y. H., Chih, Y., \& Ibbs, C. W. (2009). Towards a comprehensive understanding of public private partnerships for infrastructure development. California management review, 51(2), 51-78.

Lafont, C. (2010). Democratic Accountability and Global Governance: Challenging the state-centric Conception of Human Rights. Isegoria(43), 407-434. 
Lee, C. H., \& Yu, Y.-H. (2011). Service delivery comparisons on household connections in Taiwan's sewer public-private-partnership (PPP) projects. International Journal of Project Management, 29(8), 1033-1043. doi:10.1016/j.ijproman.2010.11.005

Lee, M., Xuehui, H., Quising, P., \& Villaruel, M. (2018). Hazard Analysis on Public-Private Partnership Projects in Developing Asia Retrieved from Philippines:

Lenferink, S., Tillema, T., \& Arts, J. (2013a). Public-private interaction in contracting: Governance strategies in the competitive dialogue of dutch infrastructure projects. Public Administration, 91(4), 928-946.

Lenferink, S., Tillema, T., \& Arts, J. (2013b). towards sustainable infrastructure development through integrated contracts: Experiences with inclusiveness in Dutch infrastructure projects. International Journal of Project Management, 31(4), 615-627.

Löfström, M. (2010). Inter-organizational collaboration projects in the public sector: A balance between integration and demarcation. International Journal of Health Planning and Management, 25(2), 136-155. doi:10.1002/hpm.1003

Miles, M. B., \& Huberman, M. (1994). Qualitative data analysis: An expanded sourcebook: sage.

Nohrstedt, D. (2016). COlLABORATIVE GOVERNANCE REGIMES. Public Administration, 94(4), 1157-+. doi:10.1111/padm.12278

O'Flynn, J. (2009). The Cult of Collaboration in Public Policy. Australian Journal of Public Administration, 68(1), 112-116. doi:10.1111/j.1467-8500.2009.00616.x

O'donnell, G. (2003). Horizontal Accountability: The Legal. Democratic Accountability in Latin America, 34.

Olsen, J. P. (2018). Democratic accountability and the changing European political order. European law journal, 24(1), 77-98. doi:10.1111/eulj.12261

Opawole, A., \& Jagboro, G. O. (2017). Factors affecting the performance of private party in concessionbased PPP projects in Nigeria. Journal of Engineering, Design and Technology, 15(1), 44-57.

Osborne, S. P. (2010). The new public governance: Emerging perspectives on the theory and practice of public governance: Routledge.

Page, S. B., Stone, M. M., Bryson, J. M., \& Crosby, B. C. (2015). PUBLIC VALUE CREATION BY CROSSSECTOR COLLABORATIONS: A FRAMEWORK AND CHALLENGES OF ASSESSMENT. Public Administration, 93(3), 715-732. doi:10.1111/padm.12161

Quelin, B. V., Kivleniece, I., \& Lazzarini, S. (2017). Public-Private Collaboration, Hybridity and Social Value: Towards New Theoretical Perspectives. Journal of Management Studies, 54(6), 763-792. doi:10.1111/joms.12274

Relly, J. E. (2012). Examining a model of vertical accountability: A cross-national study of the influence of information access on the control of corruption. Government Information Quarterly, 29(3), 335345.

Ruckert, A., \& Labonté, R. (2014). Public-private partnerships (ppps) in global health: the good, the bad and the ugly. Third World Quarterly, 35(9), 1598-1614. doi:10.1080/01436597.2014.970870

Ryan, C., \& Walsh, P. (2004). Collaboration of public sector agencies: Reporting and accountability challenges. International Journal of Public Sector Management, 17(7), 621-631. doi:10.1108/09513550410562284

Saldaña, J. (2015). The coding manual for qualitative researchers: Sage.

Schillemans, T. (2011). Does horizontal accountability work? Evaluating potential remedies for the accountability deficit of agencies. Administration \& Society, 43(4), 387-416.

Selsky, J. W., \& Parker, B. (2005). Cross-sector partnerships to address social issues: Challenges to theory and practice. Journal of Management, 31(6), 849-873.

Shaoul, J., Stafford, A., \& Stapleton, P. (2012). Accountability and corporate governance of public private partnerships. Critical Perspectives on Accounting, 23(3), 213-229. 
Smeets, D. J. A. (2017). Collaborative Learning Processes in Social Impact Bonds: A Case Study from the Netherlands. Journal of Social Entrepreneurship, 8(1), 67-87. doi:10.1080/19420676.2017.1299034

Sørensen, E., \& Torfing, J. (2009). Making governance networks effective and democratic through metagovernance. Public Administration, 87(2), 234-258.

Soubliere, J. F., \& Cloutier, C. (2015). Explaining Levels of Local Government Involvement in Service Delivery: The Dynamics of Cross-Sector Partnerships in Malawi. Public Administration and Development, 35(3), 192-205. doi:10.1002/pad.1715

Stadtler, L. (2015). Designing Public-Private Partnerships for Development. Business \& Society, 54(3), 406-421. doi:10.1177/0007650314557931

Stadtler, L. (2016). Scrutinizing public-private partnerships for development: Towards a broad evaluation conception. Journal of Business Ethics, 135(1), 71-86.

Stafford, A., \& Stapleton, P. (2017). Examining the Use of Corporate Governance Mechanisms in PublicPrivate Partnerships: Why Do They Not Deliver Public Accountability? Australian Journal of Public Administration, 76(3), 378-391. doi:10.1111/1467-8500.12237

Szmigiel-Rawska, K. (2016). Sustainability of cross-border cooperation: PHARE CBC partnership development paths. European Urban and Regional Studies, 23(3), 513-526. doi:10.1177/0969776414526734

Van Gestel, K., Willems, T., Verhoest, K., Voets, J., \& Van Garsse, S. (2014). Public-private partnerships in Flemish schools: a complex governance structure in a complex context. Public Money \& Management, 34(5), 363-370. doi:10.1080/09540962.2014.945808

Verweij, S. (2015). Achieving satisfaction when implementing PPP transportation infrastructure projects: A qualitative comparative analysis of the A15 highway DBFM project. International Journal of Project Management, 33(1), 189-200.

Vestergaard, A., Murphy, L., Morsing, M., \& Langevang, T. (2020). Cross-sector partnerships as capitalism's new development agents: Reconceiving impact as empowerment. Business \& Society, 59(7), 1339-1376.

Wilkins, P., Phillimore, J., \& Gilchrist, D. (2016). Public Sector Collaboration: Are We Doing It Well and Could We Do It Better? Australian Journal of Public Administration, 75(3), 318-330. doi:10.1111/1467-8500.12183

Wilkins, P., Phillimore, J., \& Gilchrist, D. (2017). Collaboration by the public sector: findings by watchdogs in Australia and New Zealand. Public Money \& Management, 37(3), 217-224. doi:10.1080/09540962.2017.1282249

Willems, T. (2014). Democratic accountability in public-private partnerships: The curious case of Flemish school infrastructure. Public Administration, 92(2), 340-358.

Willems, T., \& Van Dooren, W. (2016). (De) politicization dynamics in public-private partnerships (PPPs): Lessons from a comparison between UK and Flemish PPP policy. Public Management Review, $18(2), 199-220$.

World Bank. (2015). Evaluation of Rural Electrification Concessions in sub-Saharan Africa. Retrieved from

World Bank. (2017). Infrastructure finance deficit: Can public-private partnerships fill the gap? Retrieved from Kampala:

World Bank. (2019). The Private Participation in Infrastructure (PPI) Project Database has data. Retrieved from https://ppi.worldbank.org/en/ppidata

Xing, Y., Liu, Y., \& Cooper, S. C. L. (2018). Local government as institutional entrepreneur: Public-private collaborative partnerships in fostering regional entrepreneurship. British Journal of Management, 29(4), 670-690.

Yoo, C. B., Hawryszkiewycz, I., \& Kang, K. (2013). A multi-perspective approach to facilitate collaboration: A case study on australian public sector organisations. 
Figure 1: Possible Scope of Vertical and Horizontal Democratic Accountabilities

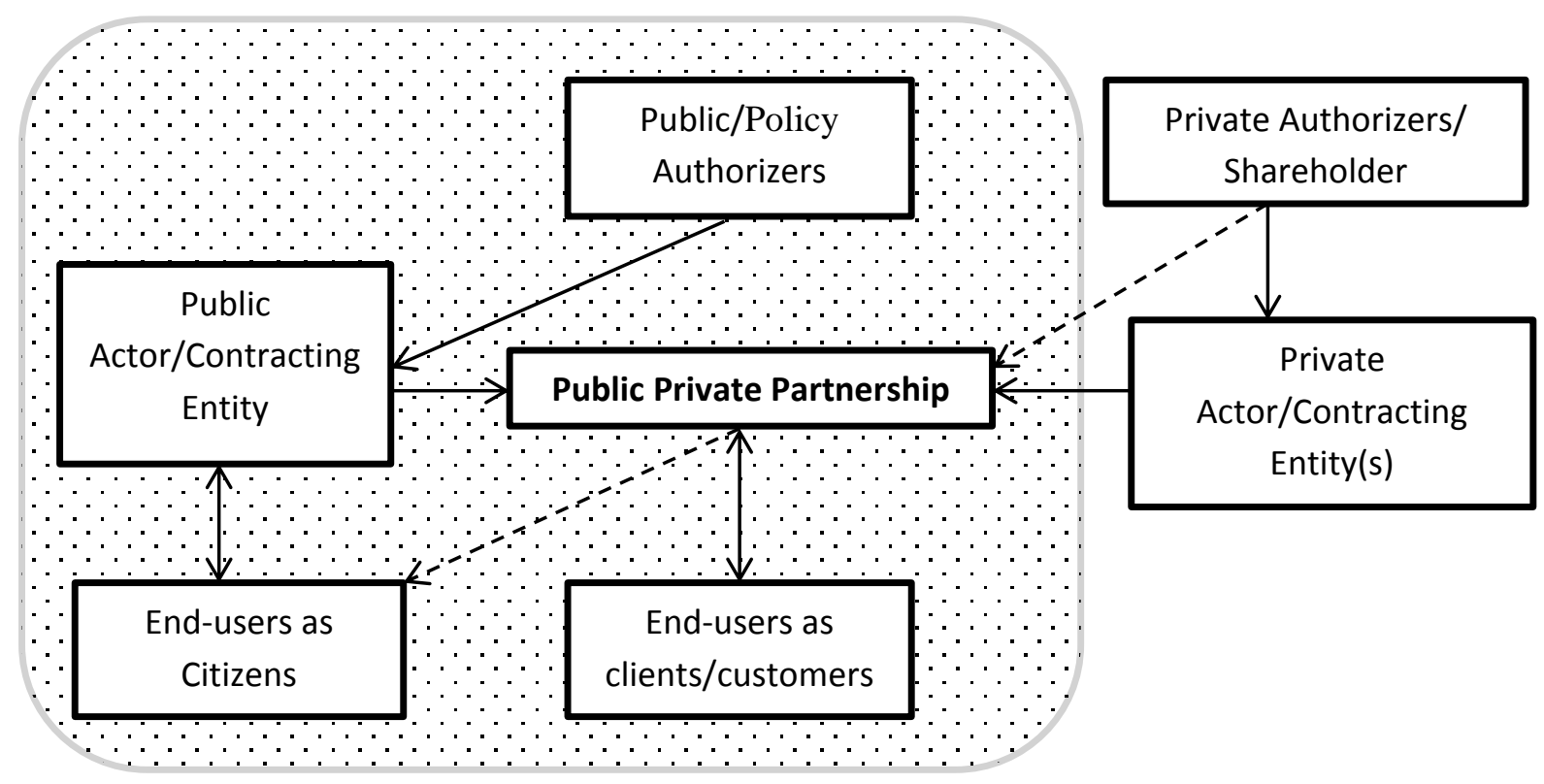


Figure 2: PPP Projects in Electricity Sector

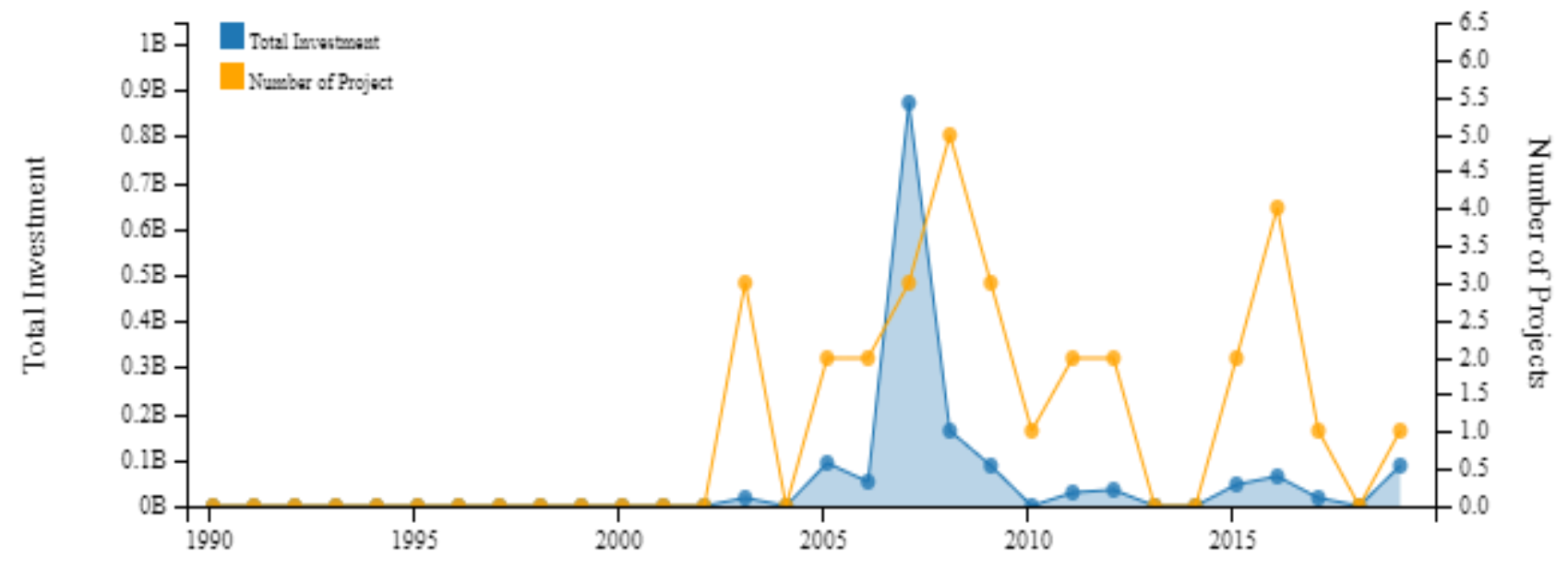

Source: World Bank PPI database 
Figure 3: PPP Projects count in Uganda

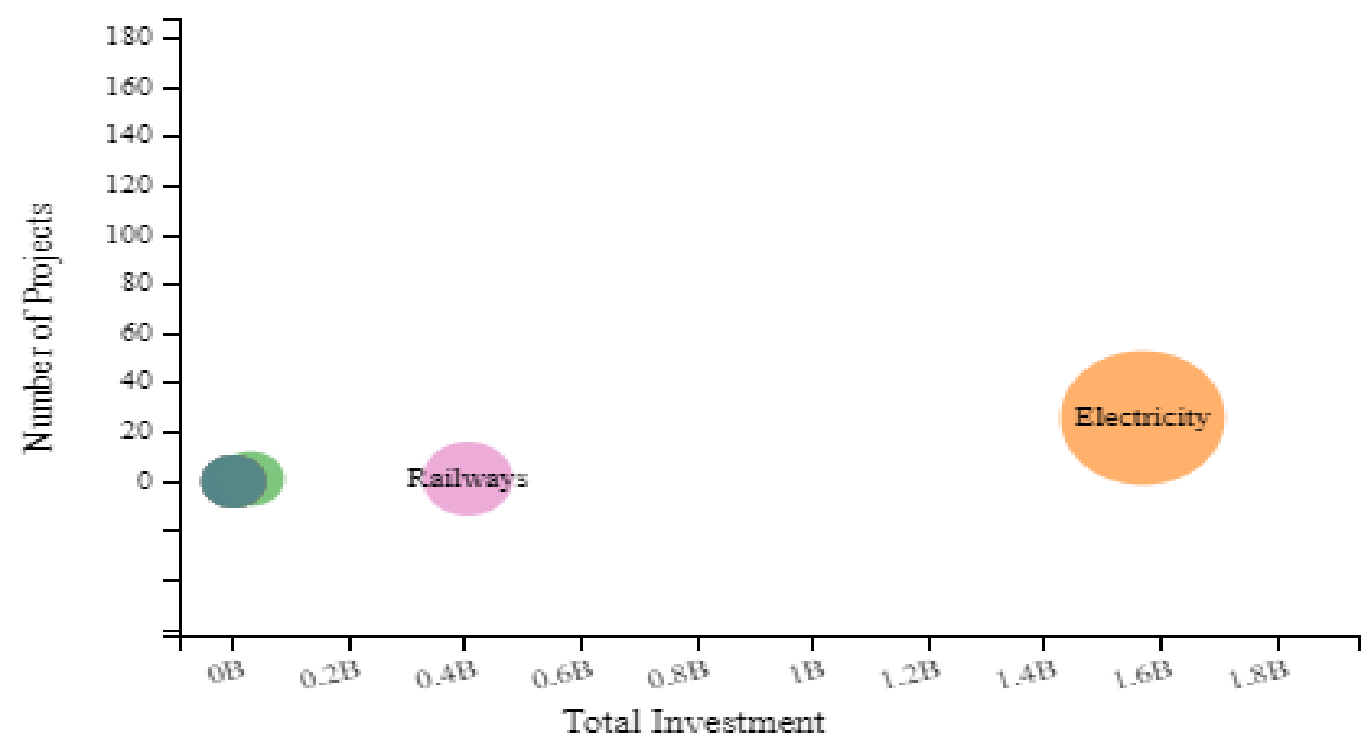

Source: World Bank PPI database 
Table 1: Summary of Empirical Findings

\begin{tabular}{|c|c|c|c|}
\hline $\begin{array}{l}\text { Engagement } \\
\text { Mechanisms }\end{array}$ & Democratic Practices & $\begin{array}{l}\begin{array}{l}\text { Interviewee understanding } \\
\text { purpose }(s)\end{array} \\
\end{array}$ & Suggested Outcome \\
\hline \multirow[t]{2}{*}{$\begin{array}{l}\text { Visibility and full } \\
\text { disclosure } \\
\text { reporting }\end{array}$} & $\begin{array}{l}\text { 1. Periodic Reviews } \\
\text { - } 7 \text { year reviews } \\
\text { - Quarterly reviews } \\
\text { - Monthly Reviews }\end{array}$ & $\begin{array}{l}\text { - Raise and address questions } \\
\text { - Clarify expectations } \\
\text { - Track status }\end{array}$ & \multirow{6}{*}{$\begin{array}{l}\text { - Increased stakeholder } \\
\text { understanding of sector } \\
\text { operations } \\
\text { - Reduced } \\
\text { misconceptions and } \\
\text { wrongful attributions }\end{array}$} \\
\hline & $\begin{array}{ll}\text { 2. } & \text { Cascaded Reporting } \\
\text { - } & \text { Vertical Sharing reports } \\
& \text { with } \\
& \text { stakeholders } \\
\end{array}$ & $\begin{array}{l}\text { - Keep other actors informed of } \\
\text { decisions and rationales } \\
\text { - Seek input of other actors }\end{array}$ & \\
\hline \multirow[t]{2}{*}{$\begin{array}{l}\text { Public Access to } \\
\text { Partnerships } \\
\text { information }\end{array}$} & $\begin{array}{l}\text { 3. Publishing of Reports } \\
\text { - Website archiving }\end{array}$ & $\begin{array}{l}\text { - Enable open access to decision } \\
\text { processes to public } \\
\text { - Allow stakeholders to validate } \\
\text { decisions against set procedures }\end{array}$ & \\
\hline & 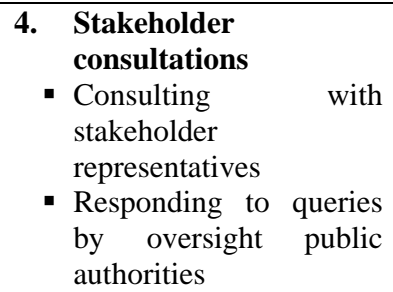 & $\begin{array}{l}\text { - Seek amicable settlement of } \\
\text { differences } \\
\text { - Clarifying the different mandates of } \\
\text { partners to external stakeholders } \\
\text { - Address misconceptions and } \\
\text { attributions }\end{array}$ & \\
\hline \multirow[t]{2}{*}{$\begin{array}{l}\text { Joint } \\
\text { implementation }\end{array}$} & $\begin{array}{ll}\text { 5. } & \text { Activity } \\
\text { Implementations } \\
\text { - Joint Asset/Investment } \\
\text { Verifications } \\
\text { - Joint intersectorial } \\
\text { reviews }\end{array}$ & $\begin{array}{l}\text { - Save resources } \\
\text { - Harmonise data and information } \\
\text { among actors } \\
\text { - Pursue common public service } \\
\text { objectives } \\
\text { - Syncronise sector level information } \\
\text { - Address cross cutting issues of } \\
\text { concern }\end{array}$ & \\
\hline & $\begin{array}{l}\text { 6. Joint implementation } \\
\text { of special projects } \\
\text { - Participation in } \\
\text { Projects/Initiative } \\
\text { for sector wide } \\
\text { support }\end{array}$ & $\begin{array}{l}\text { - Enable service affordability and } \\
\text { access } \\
\text { - Enable mutual learning to design } \\
\text { and synchronise responses } \\
\text { - Share practical implementation } \\
\text { challenges with policy actors }\end{array}$ & \\
\hline
\end{tabular}

Source: Authors 